\title{
Review
}

\section{Drought: A Common Environmental Disaster}

\author{
Israel R. Orimoloye ${ }^{1,2,3, * \mathbb{D}}$, Johanes A. Belle ${ }^{2}$, Yewande M. Orimoloye ${ }^{2}$, Adeyemi O. Olusola ${ }^{4,5}$ (D) \\ and Olusola O. Ololade ${ }^{1}$ (D)
}

1 Centre for Environmental Management, University of the Free State, Bloemfontein 9301, South Africa; shola.ololade@gmail.com

2 Disaster Management Training and Education Centre for Africa, University of the Free State, Bloemfontein 9301, South Africa; belleJA@ufs.ac.za (J.A.B.); orimoloyeyewande@gmail.com (Y.M.O.)

3 Department of Geography and Environmental Science, University of Fort Hare, Private Bag X1314, Alice 5700, South Africa

4 Department of Geography, University of the Free State, Bloemfontein 9301, South Africa; olusolaadeyemi.ao@gmail.com

5 Department of Geography, University of Ibadan, Ibadan 200284, Nigeria

* Correspondence: orimoloyeisrael@gmail.com; Tel.: +27-7-3224-4901

Citation: Orimoloye, I.R.; Belle, J.A.; Orimoloye, Y.M.; Olusola, A.O.; Ololade, O.O. Drought: A Common Environmental Disaster. Atmosphere 2022, 13, 111. https://doi.org/ 10.3390/atmos13010111

Academic Editors: María Fernández-Raga, Yang Yu and Julian Campo

Received: 15 November 2021 Accepted: 6 January 2022

Published: 11 January 2022

Publisher's Note: MDPI stays neutral with regard to jurisdictional claims in published maps and institutional affiliations.

Copyright: (C) 2022 by the authors. Licensee MDPI, Basel, Switzerland. This article is an open access article distributed under the terms and conditions of the Creative Commons Attribution (CC BY) license (https:// creativecommons.org/licenses/by/ $4.0 /)$.

\begin{abstract}
Droughts have been identified as an environmental hazard by environmentalists, ecologists, hydrologists, meteorologists, geologists, and agricultural experts. Droughts are characterised by a decrease in precipitation over a lengthy period, such as a season or a year, and can occur in virtually all climatic zones, including both high and low rainfall locations. This study reviewed drought-related impacts on the environment and other components particularly, in South Africa. Several attempts have been made using innovative technology such as earth observation and climate information as recorded in studies. Findings show that the country is naturally water deficient, which adds to the climate fluctuation with the average annual rainfall in South Africa being far below the global average of $860 \mathrm{~mm}$ per year. Drought in South Africa's Western Cape Province, for example, has resulted in employment losses in the province's agriculture sector. According to the third quarterly labor force survey from 2017, the agricultural industry lost almost 25,000 jobs across the country. In the Western Cape province, about 20,000 of these were lost which has a direct impact on income generation. Many of these impacts were linked to drought events.
\end{abstract}

Keywords: drought disaster; impacts; environment; South Africa

\section{Introduction}

Drought has been identified as an environmental hazard by scientists and agricultural professionals. It has been described as a long period of a decrease in precipitation, such as a season or a year, and occurs in almost all climatic zones, including both high and low rainfall locations. Drought is characterised by the average amount of precipitation that an area regularly receives. For example, the average annual rainfall in Atlanta, Georgia is roughly $127 \mathrm{~cm}$ (50 inches). If there is a large decrease in rainfall, water shortages may occur, and drought may be proclaimed. In a non-drought year, however, some arid locations, such as the deserts of the American Southwest, may receive less than $25 \mathrm{~cm}$ (10 inches) of rainfall. In Phoenix, Arizona, a drought in Atlanta may mean a very wet period $[1,2]$. In some other locations, such as Sub-Saharan Africa (SSA), evidence points to the long records of various drought episodes in varying magnitude and intensity. Within SSA, factors such as polity, governance, exposure, vulnerable populace and the high seasonality of rainfall make the region susceptible to drought risk. According to a report by reliefweb on droughts in SSA and Southern Africa (https:/ / reliefweb.int/sites/reliefweb.int/files / resources/GDODroughtNews202108_Sub-Saharan_and_Southern_Africa.pdf, accessed on 10 November 2021), there are five major areas of concern within this sub-continent. These areas are Southern Madagascar, Angola, Central Nigeria, Kenya, Southern Somalia 
and Northern Zambia. These areas show distinct seasonality in rainfall; one of the issues identified as a leading cause is the widespread failure of previous wet seasons, in some cases for several consecutive years. In Madagascar, the situation is very grim; about 1.31 million are affected with about $60 \%$ loss and damages recorded in the agricultural section. In Angola, the situation is no different. About 3.81 million people are experiencing food insecurity as a result of drought events afflicting the country. In Kenya, the situation is almost the same, as reports from the country are stating unequivocally that food insecurity within the country is likely to persist till the end of the year 2021 with about 2 million people in need of humanitarian aid. Whether it is in SSA, South Africa or in southern Africa, such as Madagascar, the impact of drought is worsening year by year and the rate of exposure is increasing. Across these regions, we have a large proportion of the population, especially within some of the counties, states, or provinces, which are pastoralists and agro-pastoralists. Hence, the persistence in drought would mean loss and damages to their crops and most likely the death of their animals. In addition, according to a report by the IPCC [3], the average global and ocean land surface temperature increased by 0.85 degrees Celsius between 1880 and 2012. South Asia, one of the world's most droughtprone regions, is facing water and food shortages [3-5]. Due to the current drought episodes within South Asia, the scenario could worsen even further. Furthermore, India was severely impacted by the worst drought in history, which lasted many years (1999-2003) [6]. A severe drought struck Southeast Asia in 2004, resulting in reduced water supplies for drinking and irrigation, as well as crop loss of millions of hectares [7-9]. Hence, deteriorating conditions of vegetation, increased distances to water sources, worsening livestock conditions, reduced milk production and increased number of children at risk of malnutrition are common lived experiences on a day-to-day basis as a result of these increasing drought events. Hence, there is a need for timely warning and early signals of drought [10], especially in tropical countries of the world, such as Sub-Saharan Africa.

Droughts are most common when typical weather patterns are disrupted, leading the water cycle to be disrupted. Storm tracks can be blocked for months or years due to changes in atmospheric circulation patterns [11]. This interruption can have a significant impact on the amount of precipitation that a region regularly receives [11]. Wind patterns can also have an impact on how moisture is absorbed in different areas. Scientists have discovered a relationship between drought and certain climate trends. El Nino is a weather phenomenon in which the temperature of the surface water in the Pacific Ocean along the central South American coast rises. Droughts in Indonesia, Australia and northeastern South America are linked to these warmer waters, which affect storm patterns. El Nino episodes, which occur every two to seven years, keep climate experts guessing. La Nina, on the other hand, occurs when the temperature of the surface water in the Pacific Ocean off the coast of the southern hemisphere drops. The cooler waters contribute to drier-than-normal weather in regions of North and South America, which affects storm patterns that can influence drought episodes [12,13]. El Nino and La Nina both last around a year on average. La Nina has a more complicated impact on weather patterns than El Nino. The effects of La Nina have been linked to two of the most devastating droughts in US history: The Dust Bowl of the 1930s and the Midwest drought of 1988 [14]. The connection between drought and global warming in the current phase of climate change is still up for debate. Warmer global temperatures, according to a study published in 2013 Mahlstein [14], will result in more rainfall in some parts of the world and lower rainfall in others, resulting in more flooding and droughts around the planet [15-17]. Other experts disagree with the prediction of increasing droughts, believing that global warming will result in a wetter environment around the planet. From the foregoing, it becomes abundantly clear that drought requires close monitoring, to aid in the understanding of its evolution and impacts over time. Sudden warming and associated changes can affect global circulation patterns, and consistent adjustments in drought regimes are expected to influence not only the local climate but also the global climate [18]. 
It might be difficult to identify the beginnings of a drought. Unlike many natural disasters that have immediate and spectacular consequences, such as earthquakes, tornadoes and hurricanes, drought can develop gradually and subtly [2,19]. The full impacts of long-term insufficient rainfall can take weeks, months or even years to manifest. It may also be difficult to predict the cessation of drought episodes $[19,20]$. While a single rainfall can give relief from drought in the short term, it may take weeks or months for precipitation levels to recover to normal. The beginning and end of a drought are sometimes only discernible in retrospect. Therefore, as a result of these attributes, drought events are very difficult to predict [11] but associations and precursors have been identified the world over.

Drought monitoring should be done frequently to recognise the severity of the drought, as well as its duration and spread, so that adequate preparation and mitigation of the possible negative effects on the environment, agriculture and economy may be implemented. Drought indices for quantitative drought severity estimation have been developed using meteorological and hydrological indicators, such as temperature, precipitation, soil moisture, and streamflow, as inputs in many scientific studies [21,22]. Because droughts are dynamic, new indices have been established and current ones have been enhanced for varied locations and meteorological conditions. As a result, there are now over 150 drought indicators in use in drought research [23]. The most commonly used drought indices in the literature include the Vegetation Condition Index (VCI) [24], Normalized Difference Vegetation Index (NDVI) [25], Standardized Precipitation Index (SPI) [26], Palmer drought severity index (PDSI) [27-29], US Drought Monitor (USDM) [30] and Effective Drought Index (EDI) by Byun and Wilhite [31], among others. As defined by Palmer [28], drought is the lack or shortage in hydrologic cycle or persistent low climatological index; this can quantify the scope, severity and frequency of prolonged periods of abnormally dry weather. Defining drought is a difficult task. It has to do with relatively dry weather conditions and the effects they have on the ecosystem, including human activities, such as agriculture and water management [22,23].

This study presents historical drought events, drought impacts, remote sensing and indices suitable for drought assessment, among others. The use of satellite remote sensing technology has proved to be a powerful and reliable tool for drought monitoring [32,33]. Remote sensing is most useful for describing the regional and temporal evolution of drought [33,34]. NDVI and VCI, on the other hand, are used to represent the state of the vegetation and drought severity [35].

\section{Historical Droughts}

In the past, droughts were frequently studied by scientists to put current droughts in context. Scientists must study paleoclimatology, the study of the atmosphere of prehistoric Earth, because current data from thermometers and rain gauges only go back around 100 to 150 years [11,36]. Tree rings, sediments found in lakes and oceans, ice cores, archaeological features and artefacts are all used to acquire paleoclimatic data. This enables scientists to gain a better grasp of climate patterns, including droughts that occurred millions of years ago [37-39]. Droughts that are severe and last for a long time are an unavoidable feature of natural climate cycles, according to paleoclimatic data. There have been several long-term droughts in North America, each with severe consequences [37]. Droughts are thought to have contributed to the fall of the Ancestral Puebloans in the Southwest around the 13th century, as well as the central and lower Mississippian societies during the 14th and 16th centuries [11]. The Great Drought was a climatic interval during the Holocene Epoch that affected much of what is now western America and had a significant impact on the region's vegetation, animals and prehistoric Native American cultures. The Holocene began 11,700 years ago and is still going on today [37,38]. The Great Drought affected an area that stretched from what is now Oregon to southern California and east to what is now eastern Texas; dendrochronology, or tree-ring investigations, show that it began in the year 1276 and lasted until the year 1299. 
The Great Drought had a particularly negative impact on the Ancestral Pueblo (Anasazi) and Hohokam peoples, whose agricultural economies had enabled them to construct densely populated settlements by this time [37,38]. They were forced to quit their towns and spread throughout the region after years of crop failure. Nomadic peoples were affected by parallel declines in wild food sources, and social disturbances are likely to have occurred as nomads and former farmers competed for the limited resources that survived under extremely dry conditions [38]. The Great Drought was one of the numerous severe droughts that struck the same region over the last three millennia. The Fairbank Drought of $500 \mathrm{BC}$ and the Whitewater Drought of AD 300 are two other droughts that have been identified. Notably, all of these dates appear to be linked to key shifts in North and Central American cultures [38].

In Africa, between 1400 and 1750, the Sahel region of Africa suffered a dry period that drastically affected the environment. For example, the water level in Ghana's Lake Bosumtwi dropped to the point where a complete forest developed on the lake's edge [11,40]. The tops of trees growing out of the lake, which is now more than $15 \mathrm{~m}$ (50 feet) deep, may still be seen today. By studying Earth's drought history, scientists have demonstrated that catastrophic droughts are a recurring component of nature's cycle [40]. Droughts in the recent century have been catastrophic, but they are modest in comparison to the severity of prior droughts that lasted more than a century. In addition, many severe and long-lasting droughts have occurred in Africa, including the 1999-2002 drought in northwest Africa, droughts in western Africa (Sahel) in the 1970s and 1980s, droughts in eastern Africa (Horn of Africa) in 2010-2011, and droughts in southern and southeastern Africa in 2001-2003, to name a few $[11,40]$. Before the twentieth century, the available (albeit limited) evidence demonstrates the occurrence of many extreme and multi-year droughts during each century, with the most prolonged and intense droughts occurring in the Sahel and equatorial eastern Africa [40,41]. Many physical mechanisms, such as the El Nio-Southern Oscillation (ENSO), sea surface temperature (SST) and land-atmosphere interaction, are complex and highly variable, making drought monitoring and forecasting a demanding task [40,41]. Information in Figure 1 presents the number of studies published on drought or drought disasters between the years 1921 and 2021, spanning 100 years. There were 1171 published articles for these years, where South Africa recorded about 453 articles followed by Egypt with about 187 articles published on drought-related issues. Nigeria, Kenya, Ethiopia, Tunisia and Morocco recorded about 130, 85, 77, 69 and 59 studies, respectively, during the survey period (Figure 1). Every year, drought normally strikes at least one region in Africa; it is devastating to experience the same disaster in a weather cycle that brings debilitating drought and hunger to East Africa, threatening the lives and livelihoods of millions of people in Ethiopia, Somalia and Kenya [42]. However, few to no studies were recorded on Somalia; this call for action with findings from research can proffer a solution to the drought and water-related issues in the region. 


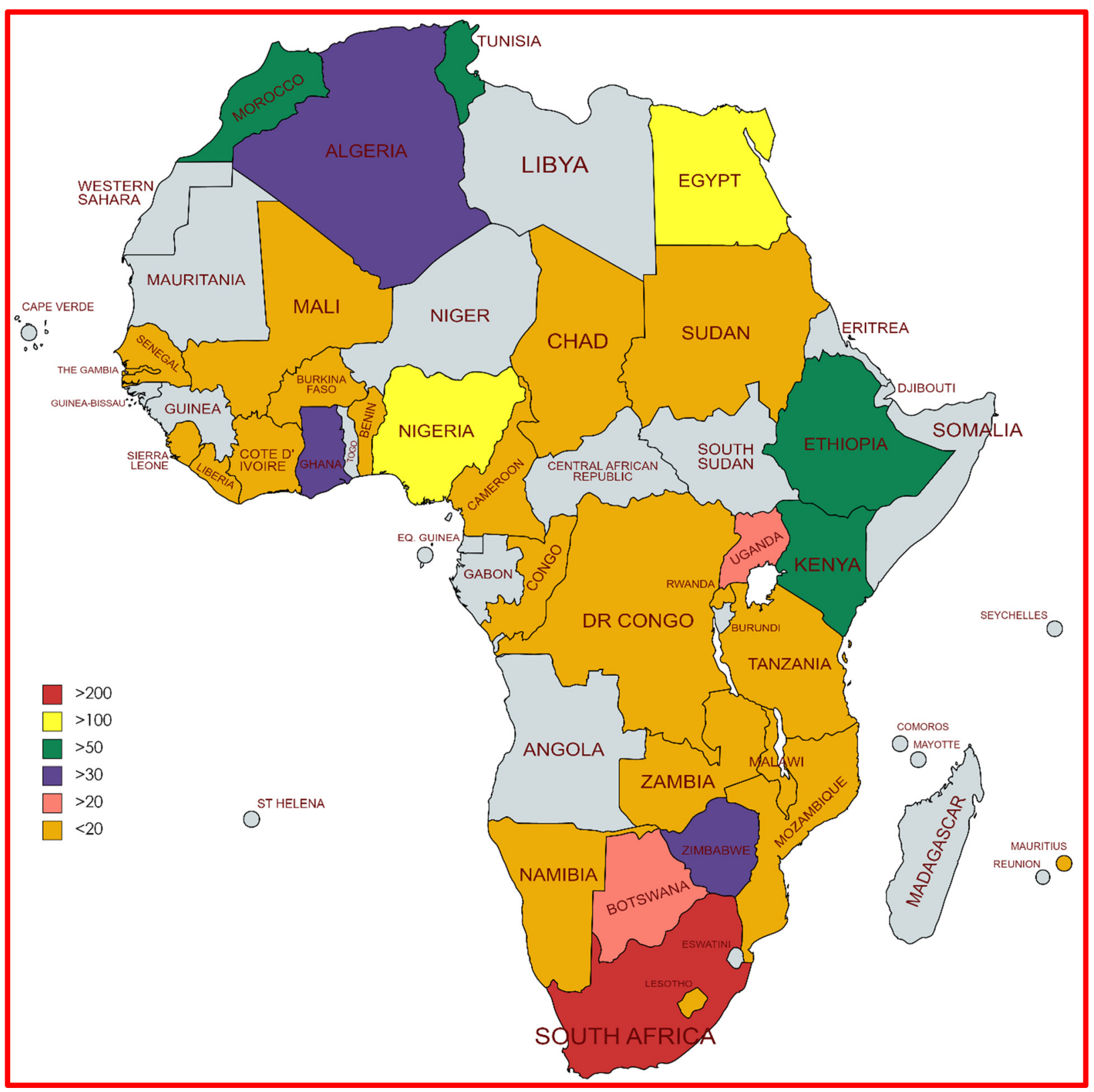

Figure 1. Studies on drought in Africa.

\section{South Africa Scenario}

Droughts are a common occurrence in South Africa's climate. Drought has an impact on society as well as on agricultural production [43]. South Africa's climate is tremendously varied over time and space due to its location at the southern tip of Africa, sandwiched between cold and warm sea currents, as well as its topography. As a result of these, the country is regarded as having one of the world's most changeable river flow regimes, with drought being one manifestation of this fluctuation [44,45]. The country is naturally water deficient, which adds to the climate fluctuation. The average annual rainfall in South Africa is far below the global average of $860 \mathrm{~mm}$ per year. Furthermore, rain falls differently across South Africa, often decreasing from east to west, with 65 percent of the country receiving less than $500 \mathrm{~mm}$ of rain each year [46,47]. Due to the country's semi-arid climate, substantial water is lost to evaporation, with evaporation from the surface exceeding the average annual rainfall in several locations. Less than $9 \%$ of the precipitation that falls on the ground makes its way into South Africa's river systems, according to estimates. This 
natural water scarcity makes South Africa particularly vulnerable to drought and water stress, as observed recently in several regions [48]. South Africa has built sophisticated bulk water storage and conveyance systems in the past to store water in times of surplus for use when needed. As a result of the rising water demand due to the population increase and socioeconomic development, many of these systems are under strain, and focus has shifted to alternative water sources, such as fog harvesting, water reclamation, desalination and groundwater, to mention a few. Drought is anticipated to become more common in South Africa as a result of climate change $[48,49]$. More so, it was as a result of an intense drought that the Water Research Commission (WRC) was established decades ago to seek solutions via research for South Africa's most pressing water questions [48,50]. The Commission has developed a range of tools and guidelines to assist local authorities in optimising their water systems and reducing water wastage.

South Africa experienced extreme droughts in the last decade; these have increased in rate and intensity, particularly in some provinces, such as the Free State and Western Cape provinces [43]. South Africa is particularly vulnerable to these new weather extremes because it relies largely on climate-sensitive industries, such as eco-tourism, agriculture, hydropower and fisheries. The country has already paid the price. Some areas of South Africa are still suffering from the infamous 2015/16 drought, which lasted well into 2018 [50,51]. Long-drought-stricken provinces, such as the Eastern Cape, are rapidly running out of water. Agriculture has been one of the most devastated industries $[46,52,53]$. As water levels declined and diseases such as anthrax and foot and mouth disease proliferated, crop production and livestock numbers plunged. Rural communities are particularly vulnerable in these circumstances. Winter crops become crucial to family food security when the major rainfed crops fail. However, the dry circumstances are already harming the aforementioned [54]. Even though weather extremes are unavoidable, their impact can be mitigated via smart planning. If not, calamities can occur, resulting in massive direct and indirect economic and societal costs; this has happened far too often in South Africa [55,56]. Due to a lack of adequate early warning systems, the country is always reacting to disasters rather than planning and implementing proactive measures in advance [48]. However, in recent times, South Africa has developed various drought mitigation measures through the effort of various agencies and departments, such as the Water Research Commission (WRC), to support policies that help protect drought-affected people by improving national coordination, monitoring, planning and preparation for extreme weather events $[48,57,58]$, especially through the use of Earth Observation products.

\section{Remote Sensing and Drought Monitoring}

Remote sensing information can be used to assess and monitor drought features because it provides real-time geographic observations of many atmospheric and land surface variables that can be utilised to estimate precipitation, evapotranspiration, soil moisture and vegetation conditions [59-61]. Traditional drought monitoring and evaluation approaches rely on rainfall data, which are scarce in some regions, frequently erroneous, and, most crucially, impossible to gather in near-real time [62]. The data from satellite sensors, on the other hand, are always available and may be used to predict the beginning of drought, as well as its duration and magnitude [63]. NOAA's National Environmental Satellite Data and Information System (NESDIS) uses the Advanced Very High-Resolution Radiometer (AVHRR) data to report on global vegetation conditions regularly for North America using the Evaporative Stress Index (ESI). Other national and global watch centres for drought exist across various platforms all over the world using a variety of indices to estimate drought conditions and provide real-time updates based on the design of the system. Data from these space-based platforms have played an increasingly important role in drought studies over the last decade, with the geographical and temporal advantages that remote sensing can provide [64]. Furthermore, the increase in space missions in Europe, America, China and Japan, to mention a few, developments in algorithm, as well as the advent of space/cloud-based processing and storage capacity, have substantially increased 
the potential of remote sensing for drought studies $[65,66]$ in the last two decades. Apart from providing an independent observational capability, remote-sensing data allow for the reduction of uncertainty and constraining of drought prediction modelling attempts [67]. With all of these advancements, growing numbers of research on drought monitoring and impacts have been published $[68,69]$. While there has been significant and important research on drought monitoring and its various impacts, with several of these studies emphasising the importance of integrated drought monitoring [70], there has been no systematic review focusing on some of the recent advances in multi-sensor remote sensing for drought studies, and how these might further advance the field [10]. Drought has complicated environmental effects and can affect multiple ecosystem components at the same time, as is well known [70,71]. A single drought index, when used alone, is unlikely to convey the complexities of process interactions and different drought impacts, whereas multisensor platforms, aided by multivariate retrievals, may better depict the extent and severity of drought conditions [70].

Drought may currently be explored from a variety of aspects using current remote sensing products, such as precipitation, air and land surface temperature, soil moisture, evaporation, total water storage and vegetation health [72]. Some remote-sensing platforms provide continuous long-term drought-related information for usage at a large scale, including the Advanced Very High-Resolution Radiometer (AVHRR) from the National Oceanic and Atmospheric Administration (NOAA) satellites that provide global coverage from 1979 to the present [73], and the Moderate Resolution Imaging Spectroradiometer (MODIS) by National Aeronautics and Space Administration (NASA) [73]. Only multi-sensor/multiplatform and remote-sensing data fusion can provide such long-term coverage. Prior to now, a single satellite sensor was unable to provide real-time drought information with high spatiotemporal resolution until the recent addition of MODIS and aperture radar [74,75], as traditional remote-sensing approaches generally require a compromise between spatial resolution and temporal frequency [76]. Drought information can be provided with high geographical and temporal precision using new systems that combine data from many sensors and platforms, or multi-sensors from satellite constellations [75,76], to overcome this spatiotemporal divide. MODIS (or Moderate Resolution Imaging Spectroradiometer) is a key instrument aboard the Terra (originally known as EOS AM-1) and Aqua (originally known as EOS PM-1) satellites. Terra's orbit around the Earth is timed so that it passes from north to south across the equator in the morning, while Aqua passes south to north over the equator in the afternoon [77]. Terra MODIS and Aqua MODIS are viewing the entire Earth's surface every 1 to 2 days, acquiring data in 36 spectral bands, or groups of wavelengths (see MODIS Technical Specifications). These data improve our understanding of global dynamics and processes occurring on the land, in the oceans and in the lower atmosphere. MODIS is playing a vital role in the development of validated, global and interactive Earth system models that are able to predict global change accurately enough to assist policymakers in making sound decisions concerning the protection of our environment [77-79]. Drought can be monitored using contemporary remote-sensing techniques or conventional climatic drought indices [80].

Drought monitoring must be efficient and timely to prevent the effects of global warming on drought [81]. Environmental variables, such as rainfall and temperature, help to solve the problem of erroneous data in spare stations [81,82]. The NDVI and Monthly Precipitation Anomaly Percentage (PA) have traditionally been used to monitor drought $[26,82,83]$. However, because the drought event does not coincide with changes in vegetation greenness, there is sometimes a lag between real drought incidence and vegetation indicators. VCI-MODIS is a new approach that combines the use of land surface temperature (LST) and NDVI [84]. The Vegetation Supply Water Index (VSWI) was proposed by Wang et al. [85] and is based on dividing the NDVI and LST. The TVDI, a triangular space index based on the NDVI and LST, was also introduced by Sandholt et al. [86]. These indexes were extensively used for drought monitoring in recent years, and they combine the benefits of LST and NDVI [87]. The TVDI, on the other hand, accurately represents 
the drought condition because it is based on data [86]. Various indices are available for drought monitoring and there is no one-size fit all approach; it depends on the drought in question, focus of the work, choice of dataset and scope.

In locations with a limited number of sampling gauges or that are inaccessible, remotesensing data may be the only available information sources for drought monitoring [88]. Drought indices based on satellite data, such as the normalized difference vegetation index (NDVI)-based vegetation condition index (VCI) [89], have been widely used to detect the onset of drought and to measure the intensity, duration and impact of drought around the world [90]. VCI has the apparent advantage of being simple to compute because it does not require station observation data, and it can offer near real-time data around the world at a relatively high spatial resolution as a satellite-based drought product [91]. The utility of the NDVI-derived VCI for monitoring drought conditions has been studied in various parts of the world, and it is strongly correlated with agricultural production in South America, Africa, Asia, North America and Europe, especially during critical crop growth periods [92]. In Kazakhstan, the VCI based on NDVI was compared to vegetation density, biomass and field reflectance data; it was shown to be a good predictor of the impact of weather on vegetation conditions and health [93]. Other research, on the other hand, has indicated that the NDVI-derived VCI should be utilised with caution. There was a limited agreement between the NDVI-derived VCI and other satellite-derived drought indices and station-based drought indices over Mongolia's desert and desert steppe regions [94]. In India, where the NDVI-derived VCI alone was proven to be insufficient for drought monitoring [95], a similar issue was observed. The NDVI-derived VCI was also evaluated in other Texas counties, with varying degrees of connection between the NDVI-derived VCI and in situ drought indices [96].

Drought research that uses numerous data sources can provide multiple lines of evidence and improve the analyses' robustness. Sensors from various equipment observe the Earth's surface features in different ways, enabling the analysis of data from a range of sources, which allows for cross-validation and a better depiction of forecast uncertainty $[70,76]$. Recent advancements in both new sensors and improved observational techniques, such as space-borne solar-induced chlorophyll fluorescence [67,70], light detection and ranging (LiDAR) and hyperspectral sensors (Jiao et al., 2019; Zhu et al., 2019), provide complementary information that can be integrated into multi-sensors [67]. Space-based or remote-sensing technology has made it possible to monitor drought, soil moisture and the condition of vegetation across large areas.

\section{Environmental Degradation and Drought}

Desertification is the degradation of arid, semi-arid and dry sub-humid environments when productivity is limited by water availability. Drought has an impact on both ecological and economic systems. Drought, similarly to land deterioration, affects almost every section of the globe, even humid areas. Land and other environmental components $[97,98]$, such as vegetation, are critical resources for food production and other ecosystem goods and services, such as biodiversity conservation, hydrological regime regulation, soil nutrient cycling and carbon storage, among others [98]. The most important geo-resource or natural capital asset is, without a doubt, productive land and fertile soil [8]. Human well-being and sustainable livelihoods are fully dependent on and closely tied to the health and productivity of the land for those people who rely largely on land as their principal asset [98], especially the poor rural; in a situation where these areas are prone to drought, livelihood will be endangered in such regions. The world's croplands and pastures grew by 154 million hectares between 1985 and 2005. Humans have removed or converted 70 percent of grassland, 50 percent of savannah, 45 percent of temperate deciduous forest and 27 percent of tropical forest biome for agriculture in the last two centuries $[99,100]$. Agriculture is thought to be responsible for roughly $80 \%$ of global deforestation [101], and productive land is growing scarce. Increased demand for productive land and water resources is caused by population growth, climate change, unsustainable land use, drought 
land degradation and expanding metropolitan areas [99]. At the same time, competition for productive land increases due to the growing demand for food, fodder and agricultural raw materials for industrial and energy use.

According to a study titled "The Economics of Desertification, Land Degradation, and Drought: Methodologies and Analysis for Decision Making", land degradation costs the global community up to 5\% of total agricultural GDP, amounting to USD 490 billion every year [102]. Land degradation has a wide range of direct economic implications of drought at the country level, with other countries suffering even greater losses due to drought episodes [103,104]. Drought has an impact on both ecological and economic systems [104]; drought, similarly to land deterioration, affects most of the world's regions, including South Africa. The fraction of the Earth's land area affected by severe drought more than doubled from the 1970s to the early 2000s $[99,100]$. Even though the world's drylands remain the most vulnerable to desertification, land degradation and drought, land degradation is a global occurrence, with 78 percent of the total degraded land occurring in terrestrial ecosystems other than drylands [105]. The links between land degradation and two other significant challenges of global environmental change are climate change and biodiversity loss, which provide another strong reason to see drought in its global context. Climate change adaptation and mitigation are inextricably linked, and land management provides a mechanism for tackling both. Maintaining and improving land quality contributes to biodiversity conservation and sustainable management, as well as providing a viable alternative to deforestation and ecosystem deterioration [106,107]. According to a recent study, rising global temperatures may cause catastrophic events to occur more frequently and with higher severity in a globally synchronised manner. On a global scale, this might drastically diminish our resistance to drought and food system disturbances [71]. With its focus on improving soil structure and land cover, Sustainable Land Management (SLM) has the potential to make significant progress toward three critical global sustainability goals related to drought, namely, food security, energy access and water availability. SLM practices significantly improve soil water retention capacity and improve water availability, as well as replenish and eliminate soils. Rural poverty can be considerably alleviated with SLM and other ecosystem-based strategies, such as drought risk management, by addressing the nexus of food, energy and water in an integrated manner.

\section{Ecosystem Services and Drought}

Drought has a variety of effects on the environment. Plants and animals, like humans, rely on water. When there is a drought, their food source may be reduced, and their habitat may be harmed. Reduced food and water supplies have resulted in an increase in sickness in wild animals [108]. Ecosystem services play a critical role in environmental management and policy development. The Millennium Ecosystem Assessment [109] defines ecosystem services as the benefits humans derive from ecosystems and includes providing, regulating, cultural and supporting services [110]. The availability of freshwater is critical to human well being and a healthy economy. Freshwater supply is a vital provisioning service that describes the ecological alteration of water utilised for a variety of uses, including drinking, irrigation, hydropower production, recreation and fisheries [111]. In addition to freshwater, food supply is another important provisioning service and is tightly linked with freshwater provisioning [110]. Drought occurrences become more intense and frequent as a result of climate change and variability, with severe effects on freshwater and food availability. During droughts, the water deficit propagates through the hydrological cycle, diminishing stream flow, lake levels and groundwater levels, and is sometimes referred to as hydrological drought. During drought periods, stream water quality may degrade due to prolonged low-flow conditions and high water temperatures [110,112,113]. Droughts that affect water availability and quality can have a significant impact on freshwater supplies. Drought, in addition to freshwater, may reduce plant growth and crop productivity due to precipitation and soil moisture shortages, potentially affecting food-provisioning services [114,115]. The 
relevance of freshwater and food supply in ensuring food security and economic growth necessitates an assessment of the effects of drought on these ecosystem services.

The number of studies on the idea and valuation of ecosystem services has risen dramatically in recent years. The relevance of considering ecosystem services when making land-use and management decisions is now widely acknowledged [110,111]. Studies on quantitative estimates of ecological services, on the other hand, are still scarce $[111,116]$. Even fewer studies have been carried out to quantify ecosystem services in response to extreme climate events, such as drought $[117,118]$. Using the Integrated Valuation of Ecosystem Services and Tradeoffs (InVEST) —an ecosystem service tool—Bangash et al. [119] assessed changes in the supply of freshwater provision and erosion control services in a Mediterranean river basin during exceptional dry and rainy years. Under future scenarios with a higher frequency of floods and droughts, the scientists reported that drinking water provisioning services decreased by 3 to 49 percent, while erosion management decreased by 5 to 43 percent. When compared to typical years, drinking water and electricity output were about 100 percent lower, while water purification services gave greater benefits in dry years [119]. In the last two decades, there has been a significant increase in the number of studies on the effects of drought on hydrology and water quality [120,121]. Summer droughts had a negative influence on water quality in the Meuse River, according to Van Vliet and Zwolsman [122]. Droughts had a negative impact on water quality in terms of water temperature, eutrophication, and some heavy metals and metalloids, while droughts had a favorable impact on nitrate. Similarly, multiple studies on the effects of drought on crop production have recently been published [10,123]. For example, Wang et al. [85] calculated the effects of climate variability on crop productivity and found that drought stress lowered the total yield by 8.1 to 17.5 percent at their four study locations in the Midwest United States. This research, on the other hand, focused on the effects of drought on variables such as stream flow, nutrient loads and crop yields. These variables are all model outputs from a process, and they could reflect ecosystem functions that contribute to ecosystem services [119]. Few studies are analysing the effects of drought on ecosystem services such as freshwater and food provisioning, as well as measuring freshwater and food provisioning using an ecosystem service-based methodology [118]. To quantify five provisional and regulatory ecosystem services, Logsdon and Chaubey [117] suggested an index-based ecosystem service approach. They established the efficacy of their methodology in an Indiana mixed land-use watershed, which could serve as a foundation for quantifying the whole range of ecosystem services.

In a warming climate, drought can have a significant impact on global and regional carbon cycling, as well as irreparable harm to ecosystem function [124,125]. According to recent research, drought combined with extremely high temperatures has a negative influence on carbon uptake, reducing the benefits of carbon dioxide and nitrogen fertilisation on terrestrial ecosystem plants. Drought has also been shown to have an increasing impact on ecosystem carbon uptake. Yuan et al. [126] found a growing influence of drought-induced vapour pressure deficit on vegetation development over the last three decades in a related investigation. The impact of drought on ecosystems, on the other hand, is complicated, and many ambiguities and issues remain unanswered [70]. Drought-related phenomena such as drought-induced tree mortality, drought-related ecosystem fire and evolving trends under climate change, for example, can be easily monitored using multi-sensor-based analyses. Multi-sensor evaluations can also help researchers better understand drought-related mechanisms, such as those underlying vegetation response and land-atmospheric feedbacks.

\section{Impact of Drought in South Africa}

Drought is South Africa's most serious disaster in terms of economic, social and environmental consequences [127]. Drought is considered by many to be the most complex and least understood of all natural hazards, affecting more people than any other hazard, according to research by the United Nations Development Programme (UNDP) [128]. Studies have demonstrated that there have been limited studies on the environmental effects 
of drought in southern Africa and particularly, South Africa [58,129]. The fundamental reason for this is that drought is commonly thought of as an agricultural or food supply issue. Drought, on the other hand, is the most significant sort of economic disruption that most southern African countries are likely to face. When developing drought management policies and programs, governments and other relevant stakeholders must consider the environmental, social and macroeconomic effects of drought. Drought has both main and secondary (ripple) consequences on the economics of households or a country. Reduced agricultural production, hydroelectric power generation, water-intensive non-agricultural production (processing) and domestic water availability, all of which have health concerns, are examples of primary or physical impacts. Secondary effects are those that have an impact on the gross domestic product (GDP); for example, a decrease in industrial output may lead to inflation and layoffs, increasing unemployment. These factors have a negative impact on demand, spending, savings and GDP. South Africa is categorised as a dual/extractive economy, with a rural economy based on subsistence agriculture and a robust urban manufacturing and service sector [130]. Information in Table 1 presents the impacts of drought, including social, environmental and economic impacts.

Table 1. Drought impacts.

\begin{tabular}{|c|c|c|c|}
\hline & Drought Impacts & Discussion & References \\
\hline SN & SOCIAL & & \\
\hline 1 & $\begin{array}{l}\text { Migration, resettlement } \\
\text { and conflicts }\end{array}$ & $\begin{array}{l}\text { As a result of the grave threat posed by drought, the United Nations } \\
\text { estimates that millions of people in drought-prone areas of Sub-Saharan } \\
\text { Africa would be compelled to migrate to North Africa or Europe in the } \\
\text { next few decades. It has an impact on various habitats, such as } \\
\text { savannahs, in addition to dry regions. Forced migration can occur due to } \\
\text { a variety of factors. It frequently occurs as a result of life-threatening } \\
\text { circumstances, such as crisis or famine, due to drought episodes. }\end{array}$ & {$[131,132]$} \\
\hline 2 & $\begin{array}{c}\text { Poverty and } \\
\text { unemployment }\end{array}$ & $\begin{array}{l}\text { For example, in the Western Cape province affected by drought recently, } \\
\text { the tourism industry in the province suffered as a result of the drought. } \\
\text { The number of tourists visiting the province decreased during the } \\
\text { drought, even though the impact has yet to be quantified. This was } \\
\text { reflected in the fact that the number of overnight guests in the region } \\
\text { increased by only } 1 \% \text { year over the year from } 2016 \text { to } 2017 \text {, compared to } \\
7 \% \text { a year earlier. Bookings at some hotels decreased by } 10 \% \text { to } 15 \% \text { in } \\
2018 \text { compared to } 2017 \text {. Tourism is anticipated to employ almost } 300,000 \\
\text { people in the Western Cape, of which a large number of them have been } \\
\text { relieved of their jobs. }\end{array}$ & {$[133,134]$} \\
\hline
\end{tabular}

Drought can affect human health, result in conflicts and impact our quality of life. Increased dust levels due to drought occurrence could be

Overstocking and reduced quality of living harmful to persons with respiratory issues, and wildfires sparked by the

[135-137] livelihoods are inextricably linked to land and water are more likely to be stressed, anxious or depressed.
$4 \quad$ Reduced or no income

Malnutrition and famine, and civil strife and conflict
Changing climate patterns, particularly droughts, have a negative impact on farmers and can result in food insecurity. As a result, farmers' and their families' incomes decline, pushing them deeper into poverty.

The drought's economic and health effects have pushed millions of people deeper into poverty and suffering. Drought's secondary effects are still being felt by children and their communities across Africa. This means fewer employment prospects, reduced livelihoods, lower economic output and restricted access to basic food and services.
$[138,139]$ 
Table 1. Cont.

\begin{tabular}{|c|c|c|c|}
\hline & Drought Impacts & Discussion & References \\
\hline SN & SOCIAL & & \\
\hline 6 & $\begin{array}{l}\text { Social unrest } \\
\text { and distrust }\end{array}$ & $\begin{array}{l}\text { The key causes that have aggravated the problem of food production, } \\
\text { distribution, and access are drought and conflict. Within an already } \\
\text { tough setting of fragile ecosystems, high rates of population increase and } \\
\text { poverty have also played a role. Because about } 80 \% \text { of the population in } \\
\text { the region lives in rural areas and relies almost entirely on agriculture for } \\
\text { food and income, solutions to poverty and food insecurity must be found } \\
\text { primarily in the agricultural sector. }\end{array}$ & [140] \\
\hline 7 & $\begin{array}{l}\text { Increased threat to } \\
\text { human and animal life }\end{array}$ & $\begin{array}{l}\text { Drought has a variety of effects on humans and animals. Plants and } \\
\text { animals, similar to humans, rely on water. When there is a drought, their } \\
\text { food source may be reduced, and their habitat may be harmed; South } \\
\text { Africa is not excepted from these impacts. }\end{array}$ & {$[141,142]$} \\
\hline 8 & $\begin{array}{l}\text { Social pressure and } \\
\text { reduced safety }\end{array}$ & $\begin{array}{l}\text { Drought has the potential to affect people's health and safety. } \\
\text { Drought-related effects on society include anxiety or depression over } \\
\text { economic losses due to drought, conflicts when there is insufficient water, } \\
\text { reduced incomes, fewer recreational activities, increased heat stroke } \\
\text { incidences and even human death. }\end{array}$ & [143] \\
\hline
\end{tabular}

\section{Environmental}

Drought conditions can also significantly enhance the risk of wildfire. Plants and trees wither and die as a result of a lack of water, increased bug infestations and diseases, all of which are linked to drought, as they

$1 \quad$ Loss of biodiversity become fuel for wildfires. Long periods of drought can lead to more and more destructive wildfires, which have a wide range of consequences for the economy, the environment and society, including the destruction of neighborhoods, crops and habitats.

Drought can cause lower water levels in reservoirs, lakes and ponds, as well as decreased river flow. This reduction in accessible water may result in the loss of some wetlands, groundwater depletion and even

Environmental degradation water quality issues (e.g., salt concentration can increase due to drought episodes). Inadequate water supply can lead to soils that are unable to support crops, increased dust owing to drought and erosion and a higher risk of wildfires due to the dry climate.

Drought is one of the causes of malnutrition and hunger, as it affects agricultural production, resulting in food insecurity in South Africa. Drought is the primary cause of global grain output shortages relative to consumption in the first half of the twenty-first century, posing a threat to food security. The 2015-2016 drought event (attributed to a strong El

Niño) in southern Africa further highlighted its vulnerability to climate-related regional food insecurity.

Droughts aggravate water scarcity, putting people's health and productivity at risk. A crucial climate change mitigation strategy for the coming years is to ensure that everyone has access to sustainable water and sanitation services. Fish, animals and plant life can be harmed by a lack of water and soil's inability to grow crops. Plant growth may be

Lower accessibility to water 
Table 1. Cont.

\begin{tabular}{|c|c|c|c|}
\hline & Drought Impacts & Discussion & References \\
\hline SN & SOCIAL & & \\
\hline 5 & $\begin{array}{c}\text { Plant and } \\
\text { vegetation scorching }\end{array}$ & $\begin{array}{l}\text { Animals and plant life can be impacted by a lack of water and soil's } \\
\text { inability to grow crops. Plant growth may be hampered by poor soil } \\
\text { quality and insufficient water due to drought, and animals may not have } \\
\text { enough to drink. There may also be a risk of endangered species } \\
\text { becoming stressed, as well as a loss of biodiversity in the affected area. It } \\
\text { might take years for many woody plants and vegetation to show } \\
\text { detrimental long-term impacts after a drought. A single drought event } \\
\text { may cause leaf scorch. If the drought persists, the entire leaf will perish. } \\
\text { Stem dieback, which is caused by the loss of tiny feeder roots, is a } \\
\text { common long-term impact of drought. }\end{array}$ & [147-150] \\
\hline
\end{tabular}

During drought conditions, fuels for wildfire, such as grasses and trees, can dry out and become more flammable. Droughts can be exacerbated by exceptionally warm weather. Extreme heat, when combined with

6 Increased fire hazard extremely low precipitation and high temperature, can result in reduced streamflow, dry soils and large-scale tree loss. Extreme wildfires are more likely to spread quickly, burn with greater severity and be costly to put out under these conditions.

$7 \quad \begin{gathered}\text { Crop withering } \\ \text { and dying }\end{gathered}$
and dying

$8 \quad$ Loss of arable land
Drought has a perhaps unique impact on agricultural systems because of its duration, which often extends over several seasons.

Drought, inappropriate land use (such as monocultures) and unsustainable land management methods, such as deforestation, improper farming practices and overexploitation of water resources) can all contribute to land degradation and loss of arable land, which is exacerbated by drought.

Extreme weather events, such as droughts, lead to contamination of soil; agricultural lands; water, food and animal feed with pathogens;

chemicals and other hazardous. Infectious disease outbreaks may be a direct consequence of drought. When rainfall decreases, viruses,

protozoa and bacteria can pollute both groundwater and surface water.

People who draw their drinking water from private wells may be more susceptible to infectious diseases caused by the drought.

\section{ECONOMIC}

Drought-related impacts exist in a variety of forms. Farmers who lose money because drought destroys their crops, or ranchers who may have to spend more money feeding and watering their livestock, are examples

Increased prices for farming commodities of economic effects. Direct economic effects, such as declines in dairy production, and indirect effects, such as rises in cheese prices, are also possible.
Drought in South Africa's Western Cape province, for example, has resulted in employment losses in the province's agriculture sector. According to the third quarterly labor force survey from 2017, the agricultural industry lost almost 25,000 jobs across the country. In the Western Cape province, about 20,000 of these were lost, which has a direct impact on income generation. Many of these impacts were linked to drought events.

Decreases in feed availability due to drought can lead to stunted growth, decrease milk production in dairy cattle and lower quality in beef, which can influence a low-income generation. The weakening product-to-feed ratio, driven by the higher feed prices, will reduce profit margins

Drought reduces cargo-carrying capacity and reduces accessible water-based transportation routes. Higher temperatures, which frequently accompany drought, can influence pavement performance, impacting roadways and airport runways, as well as collapsing rail lines.
Sale of livestock at reduced market price 
Table 1. Cont.

\begin{tabular}{|c|c|c|c|}
\hline & Drought Impacts & Discussion & References \\
\hline SN & SOCIAL & & \\
\hline 6 & $\begin{array}{c}\text { Deepening poverty and } \\
\text { increased } \\
\text { unemployment }\end{array}$ & $\begin{array}{l}\text { The drought vulnerability in South Africa, especially in the affected } \\
\text { provinces, is driven by extensive soil erosion, which is a result of the } \\
\text { communal land-use system and limited access to information and } \\
\text { infrastructure as well as low-income levels and high unemployment. }\end{array}$ & {$[138]$} \\
\hline 7 & $\begin{array}{c}\text { Increased } \\
\text { capital shortfall }\end{array}$ & $\begin{array}{l}\text { With the recent drought hazards in some regions of South Africa, the } \\
\text { economic and livelihood have been severely affected due to these } \\
\text { hazards. All of these have huge economic consequences. South Africa's } \\
\text { economy grew at an annual pace of } 1.1 \text { percent on average from } 2015 \text { to } \\
\text { 2017, with the agricultural sector increasing at less than } 0.5 \text { percent. That } \\
\text { is insufficient to address the country's most pressing issues, which } \\
\text { include high rates of inequality, poverty and unemployment. }\end{array}$ & {$[133]$} \\
\hline 8 & $\begin{array}{l}\text { Increased debt and } \\
\text { increased credit risk for } \\
\text { financial institutions }\end{array}$ & $\begin{array}{l}\text { Farmers are more vulnerable to drought because almost all their } \\
\text { livelihood income depends on farming, the unemployment rate is very } \\
\text { high and opportunities for alternative jobs are scarce. More so, some } \\
\text { farmers that are on loan or borrowed money from banks or other } \\
\text { financial institutions are indebted with credit risk. }\end{array}$ & {$[138]$} \\
\hline
\end{tabular}

As highlighted in Table 1, a seasonal-scale drought evaluation and forecasting system can potentially support an early warning system, as it can provide updated drought-related events and its potential impacts on a timely basis by accounting for the drought conditions as of the forecast release date and climate outlook over the forecast period [126,145,160]. However, thus far, the application of space-based information for food insecurity early warnings in South Africa and other African nations has been limited at best, with the only other main example being the African Flood and Drought Monitor [161].

Droughts, unlike other weather-related disasters that make headlines because of immediate obvious devastation, are slow-burning calamities with long-term consequences. Severe drought, on the other hand, has far-reaching consequences for society and ecosystems:

Agriculture: Increased temperatures and water stress cause agricultural losses, which can devastate farmers who rely on crop yields for their livelihood. Increasingly dry rangeland has a negative influence on cattle output; feeding and hydrating huge herds becomes more challenging.

Ecosystems: As bodies of water dry up due to drought, huge fish deaths can occur. Droughts can also cause pest outbreaks, wildlife losses and forest diebacks, all of which threaten the viability of the important ecological services that humans rely on.

Infrastructure: Drought may cause reductions in outdoor recreation sectors, and shifting soil and moisture levels can destroy physical infrastructure. Drought conditions will undoubtedly increase the likelihood and severity of devastating wildfires.

Economy: Droughts have cost billions of dollars in damages since 1980, with an average annual cost of $\$ 9$ billion since 2010 [162].

Therefore, droughts are likely to last longer and become more severe in the coming years. This is because continuous emissions of heat-trapping gases are expected to result of even more warming. While we can expect more rainfall around the world, experts estimate that evaporation may surpass precipitation, resulting in more frequent and extended drought periods [162].

\section{Summary}

This review focused on the effects of drought on the environment and other factors in South Africa. The findings demonstrate that the country is inherently water-scarce, which contributes to climate change impacts, as South Africa's average annual rainfall is much below the global average of $860 \mathrm{~mm}$ per year. Drought in the Western Cape province of South Africa, for example, has resulted in job losses in the agriculture sector. In 2017, 
the agricultural business lost about 25,000 jobs across the country, according to the third quarterly labour force survey. Approximately 20,000 of these were lost in the Western Cape province, resulting in a direct impact on income creation. In addition, the impact of drought is extensive and grim. It affects all the components of the physical environment and in essence limits not only the economy of the state but also the smooth functioning of the natural environment. Indirectly, drought episodes also result in issues of mental health not only for the farmers but other vulnerable groups such as but not limited to young children, women and the aged.

At the moment, most drought indices are drought-type-specific; available indices focus on a type of drought to a large extent. There is a need to develop more robust drought indicators that can serve as a unique identifier for most of the drought types. The emergence of deep learning in recent times could also be employed to help in drought predictions to aid early warning and reduce losses and damages.

Funding: This research received no external funding.

Institutional Review Board Statement: Not applicable.

Informed Consent Statement: Not applicable.

Data Availability Statement: Information and data used in the study will be provided on reasonable request.

Conflicts of Interest: The authors declare no conflict of interest.

\section{References}

1. Haile, G.G.; Tang, Q.; Li, W.; Liu, X.; Zhang, X. Drought: Progress in broadening its understanding. Wiley Interdiscip. Rev. Water 2020, 7, e1407. [CrossRef]

2. Cravens, A.E.; Henderson, J.; Friedman, J.; Burkardt, N.; Cooper, A.E.; Haigh, T.; Hayes, M.; McEvoy, J.; Paladino, S.; Wilke, A.K.; et al. A typology of drought decision making: Synthesizing across cases to understand drought preparedness and response actions. Weather. Clim. Extrem. 2021, 33, 100362. [CrossRef]

3. IPCC. Climate Change 2014: Mitigation of climate change. In Contribution of Working Group III to the Fifth Assessment Report of the Intergovernmental Panel on Climate Change; Cambridge University Press: Cambridge, UK, 2014.

4. World Bank. Pakistan Country Water Resources Assistance Strategy Water Economy: Running Dry; South Asia Region, Agriculture and Rural Development Unit: Washington, DC, USA, 2005.

5. Munir, M.U.; Ahmad, A.; Hopmans, J.W.; Belgacem, A.O.; Baig, M.B. Water scarcity threats to National Food Security of Pakistan-Issues, implications, and way forward. In Emerging Challenges to Food Production and Security in Asia, Middle East, and Africa; Springer: Cham, Switzerland, 2021; pp. 241-266.

6. Haroon, M.A.; Zhang, J.; Yao, F. Drought monitoring and performance evaluation of MODIS-based drought severity index (DSI) over Pakistan. Nat. Hazards 2016, 84, 1349-1366. [CrossRef]

7. NBS. China Statistical Yearbook, 2004; National Bureau of Statistics of China: Beijing, China, 2005.

8. Liu, Y.; Teixeira, J.L.; Zhang, H.J.; Pereira, L.S. Model validation and crop coefficients for irrigation scheduling in the North China Plain. Agric. Water Manag. 1998, 36, 233-246. [CrossRef]

9. Pereira, L.S.; Teodoro, P.R.; Rodrigues, P.N.; Teixeira, J.L. Irrigation scheduling simulation: The model ISAREG. In Tools for Drought Mitigation in Mediterranean Regions; Springer: Dordrecht, The Netherlands, 2003; pp. 161-180.

10. Adedeji, O.; Olusola, A.; James, G.; Shaba, H.A.; Orimoloye, I.R.; Singh, S.K.; Adelabu, S. Early warning systems development for agricultural drought assessment in Nigeria. Environ. Monit. Assess. 2020, 192, 798. [CrossRef]

11. Jeannie Evers and Caryl-Sue. National Geographic Magazine: The New Dust Bowl. 2013. Available online: https://www. nationalgeographic.org/article/understanding-droughts/ (accessed on 10 November 2021).

12. Zanin, P.R.; Satyamurty, P. Hydrological processes interconnecting the two largest watersheds of South America from multidecadal to inter-annual time scales: A critical review. Int. J. Climatol. 2020, 40, 4006-4038. [CrossRef]

13. Tucker, C.S.; Pearl, J.K. Coastal tree-ring records for paleoclimate and paleoenvironmental applications in North America. Quat. Sci. Rev. 2021, 265, 107044. [CrossRef]

14. Heim, R.R., Jr. A comparison of the early twenty-first century drought in the United States to the 1930s and 1950s drought episodes. Bull. Am. Meteorol. Soc. 2017, 98, 2579-2592. [CrossRef]

15. Mahlstein, I.; Daniel, J.S.; Solomon, S. Pace of shifts in climate regions increases with global temperature. Nat. Clim. Chang. 2013, 3, 739-743. [CrossRef]

16. Trenberth, K.E.; Jones, P.D.; Ambenje, P.; Bojariu, R.; Easterling, D.; Klein Tank, A.; Parker, D.; Rahimzadeh, F.; Renwick, J.A.; Rusticucci, M.; et al. Chapter 3. Observations. Surface and atmospheric climate change. In Climate Change 2007: Working Group I: The Physical Science Basis; IPCC: Nairobi, Kenya, 2007. 
17. Solomon, S.; Qin, D.; Manning, M.; Chen, Z.; Marquis, M.; Averyt, K.B.; Tignor, M.; Miller, H.L. The physical science basis. In Contribution of Working Group I to the Fourth Assessment Report of the Intergovernmental Panel on Climate Change; 2007; pp. 235-337. Available online: https://www.ipcc.ch/site/assets/uploads/2018/02/ar4-wg1-frontmatter-1.pdf (accessed on 10 November 2021).

18. Dai, A. Drought under global warming: A review. Wiley Interdiscip. Rev. Clim. Chang. 2011, 2, 45-65. [CrossRef]

19. Wu, J.; Chen, X.; Yao, H.; Liu, Z.; Zhang, D. Hydrological drought instantaneous propagation speed based on the variable motion relationship of speed-time process. Water Resour. Res. 2018, 54, 9549-9565. [CrossRef]

20. Nesbit, J. This Is the Way the World Ends: How Droughts and Die-Offs, Heat Waves and Hurricanes are Converging on America; Thomas Dunne Books; St. Martin's Press: New York, NY, USA, 2018.

21. Choi, M.; Jacobs, J.M.; Anderson, M.C.; Bosch, D.D. Evaluation of drought indices via remotely sensed data with hydrological variables. J. Hydrol. 2013, 476, 265-273. [CrossRef]

22. Baig, M.H.A.; Abid, M.; Khan, M.R.; Jiao, W.; Amin, M.; Adnan, S. Assessing meteorological and agricultural drought in Chitral Kabul river basin using multiple drought indices. Remote Sens. 2020, 12, 1417. [CrossRef]

23. Niemeyer, S. New drought indices. Options Méditerranéennes. Série A Séminaires Méditerranéens 2008, 80, 267-274.

24. Zambrano, F.; Lillo-Saavedra, M.; Verbist, K.; Lagos, O. Sixteen years of agricultural drought assessment of the BioBío region in Chile using a $250 \mathrm{~m}$ resolution Vegetation Condition Index (VCI). Remote Sens. 2016, 8, 530. [CrossRef]

25. Rafiei Sardooi, E.; Azareh, A.; Eskandari Damaneh, H.; Skandari Damaneh, H. Drought Monitoring Using MODIS Land Surface Temperature and Normalized Difference Vegetation Index Products in Semi-Arid Areas of Iran. J. Rangel. Sci. 2021, 11, 402-418

26. McKee, T.B.; Doesken, N.J.; Kleist, J. The relationship of drought frequency and duration to time scales. In Proceedings of the 8th Conference on Applied Climatology, Anaheim, CA, USA, 17-22 January 1993; Volume 17, pp. 179-183.

27. Palmer, W.C. Keeping Track of Crop Moisture Conditions, Nationwide: The New Crop Moisture Index. Weatherwise 1968, 21, 156-161. [CrossRef]

28. Palmer, W.C. Meteorological Drought; US Department of Commerce, Weather Bureau; National Weather Service: Washington, WA, USA, 1965; Volume 30.

29. Van der Schrier, G.; Barichivich, J.; Briffa, K.R.; Jones, P.D. A scPDSI-based global data set of dry and wet spells for 1901-2009. J. Geophys. Res. Atmos. 2013, 118, 4025-4048. [CrossRef]

30. Kuwayama, Y.; Thompson, A.; Bernknopf, R.; Zaitchik, B.; Vail, P. Estimating the impact of drought on agriculture using the US Drought Monitor. Am. J. Agric. Econ. 2019, 101, 193-210. [CrossRef]

31. Byun, H.R.; Wilhite, D.A. Objective quantification of drought severity and duration. J. Clim. 1999, 12, 2747-2756. [CrossRef]

32. Abbas, S.; Nichol, J.E.; Qamer, F.M.; Xu, J. Characterization of drought development through remote sensing: A case study in Central Yunnan, China. Remote Sens. 2014, 6, 4998-5018. [CrossRef]

33. Ali, S.; Tong, D.; Xu, Z.T.; Henchiri, M.; Wilson, K.; Siqi, S.; Zhang, J. Characterization of drought monitoring events through MODIS-and TRMM-based DSI and TVDI over South Asia during 2001-2017. Environ. Sci. Pollut. Res. 2019, $26,33568-33581$. [CrossRef] [PubMed]

34. MAO, K.B.; Ying, M.A.; Lang, X.I.A.; Tang, H.J.; Han, L.J. The monitoring analysis for the drought in China by using an improved MPI method. J. Integr. Agric. 2012, 11, 1048-1058. [CrossRef]

35. Wang, H.; Lin, H.; Liu, D. Remotely sensed drought index and its responses to meteorological drought in Southwest China. Remote Sens. Lett. 2014, 5, 413-422. [CrossRef]

36. Cook, E.R.; Seager, R.; Cane, M.A.; Stahle, D.W. North American drought: Reconstructions, causes, and consequences. Earth-Sci. Rev. 2007, 81, 93-134. [CrossRef]

37. Stahle, D.W.; Cook, E.R.; Cleaveland, M.K.; Therrell, M.D.; Meko, D.M.; Grissino-Mayer, H.D.; Watson, E.; Luckman, B.H. Tree-ring data document 16th century megadrought over North America. Eos Trans. Am. Geophys. Union 2000, 81, 121-125. [CrossRef]

38. Pallardy, R. The Editors of Encyclopaedia Britannica. 2021. Available online: https://www.britannica.com/event/Great-Drought (accessed on 10 November 2021).

39. WMO. State of Global Climate 2020. WMO-No.1264. 2021. Available online: https://library.wmo.int/?lvl=notice_display\&id=21 880\#.Ydgf-GhBzIU (accessed on 10 November 2021).

40. Masih, I.; Maskey, S.; Mussá, F.E.F.; Trambauer, P. A review of droughts on the African continent: A geospatial and long-term perspective. Hydrol. Earth Syst. Sci. 2014, 18, 3635-3649. [CrossRef]

41. Orlove, B.S.; Tosteson, J.L. The Application of Seasonal to Interannual Climate Forecasts Based on El Niño-Southern Oscillation (ENSO) Events: Australia, Brazil, Ethiopia, Peru, and Zimbabwe. 1999. Available online: https://escholarship.org/uc/item/4b8 8q4mj (accessed on 10 November 2021).

42. Sibanda, W.; Sibanda, F. Chapter Three climate change and the future of Africa: Impacts on water resources in Eastern and Southern Africa. In Necroclimatism in a Spectral World (Dis)order?: Rain Petitioning, Climate and Weather Engineering in 21st Century Africa; Langaa RPCIG: Bamenda, Cameroon, 2019; pp. 109-132.

43. Botai, C.M.; Botai, J.O.; Dlamini, L.C.; Zwane, N.S.; Phaduli, E. Characteristics of droughts in South Africa: A case study of free state and North West Provinces. Water 2016, 8, 439. [CrossRef]

44. Bhaga, T.D.; Dube, T.; Shekede, M.D.; Shoko, C. Impacts of climate variability and drought on surface water resources in Sub-Saharan Africa using remote sensing: A review. Remote Sens. 2020, 12, 4184. [CrossRef] 
45. Makaya, E.; Rohse, M.; Day, R.; Vogel, C.; Mehta, L.; McEwen, L.; Rangecroft, S.; Van Loon, A.F. Water governance challenges in rural South Africa: Exploring institutional coordination in drought management. Water Policy 2020, 22, 519-540. [CrossRef]

46. Graw, V.; Ghazaryan, G.; Dall, K.; Delgado Gómez, A.; Abdel-Hamid, A.; Jordaan, A.; Piroska, R.; Post, J.; Szarzynski, J.; Walz, Y.; et al. Drought dynamics and vegetation productivity in different land management systems of Eastern Cape, South Africa-A remote sensing perspective. Sustainability 2017, 9, 1728. [CrossRef]

47. Makhale, A. The Influence of Rainfall on the Distribution of Burchell's Zebra (Equusburchelli) in Kruger National Park, South Africa. Doctoral Dissertation, University of Venda, Thohoyandou, South Africa, 2018.

48. Drought, S.A. Drought South Africa. 2020. Available online: https://www.droughtsa.org.za/for-municipalities/ (accessed on 10 November 2021).

49. Mehr, A.D.; Vaheddoost, B.; Mohammadi, B. ENN-SA: A novel neuro-annealing model for multi-station drought prediction. Comput. Geosci. 2020, 145, 104622. [CrossRef]

50. Mpandeli, S.; Naidoo, D.; Mabhaudhi, T.; Nhemachena, C.; Nhamo, L.; Liphadzi, S.; Hlahla, S.; Modi, A.T. Climate change adaptation through the water-energy-food nexus in southern Africa. Int. J. Environ. Res. Public Health 2018, 15, 2306. [CrossRef] [PubMed]

51. Chevallier, R.; Bijoux, J.; Macamo, C.; Sauka, S. Marine and Coastal Ecosystem-Based Adaptation for Enhanced Resilience in Southern Africa: Synthesis Report. 2019. Available online: https://www.africaportal.org/publications/marine-and-coastalecosystem-based-adaptation-enhanced-resilience-southern-africa-synthesis-report/ (accessed on 15 November 2021).

52. Ngaka, M.J. Drought preparedness, impact and response: A case of the Eastern Cape and Free State provinces of South Africa. Jàmbá J. Disaster Risk Stud. 2012, 4, 1-10. [CrossRef]

53. Mahlalela, P.T.; Blamey, R.C.; Hart, N.C.G.; Reason, C.J.C. Drought in the Eastern Cape region of South Africa and trends in rainfall characteristics. Clim. Dyn. 2020, 55, 2743-2759. [CrossRef]

54. Bahta, Y.T.; Jordaan, A.; Phatudi-Mphahlele, B. Ecological vulnerability indicators to drought: Case of communal farmers in Eastern Cape, South Africa. Jàmbá J. Disaster Risk Stud. 2019, 11, 1-11.

55. Masupha, T.E.; Moeletsi, M.E. Use of standardized precipitation evapotranspiration index to investigate drought relative to maize, in the Luvuvhu River catchment area, South Africa. Phys. Chem. Earth Parts A/B/C 2017, 102, 1-9. [CrossRef]

56. Vogel, C.; Olivier, D. Re-imagining the potential of effective drought responses in South Africa. Reg. Environ. Chang. 2019, 19, 1561-1570. [CrossRef]

57. Allen, R.G.; Pereira, L.S.; Raes, D.; Smith, M. Crop Evapotranspiration-Guidelines for Computing Crop Water Requirements-FAO Irrigation and Drainage Paper 56; FAO: Rome, Italy, 1998; ISBN 92-5-104219-5.

58. Nhamo, L.; Mabhaudhi, T.; Modi, A.T. Preparedness or repeated short-term relief aid? Building drought resilience through early warning in southern Africa. Water SA 2019, 45, 75-85. [CrossRef]

59. Su, Z.; He, Y.; Dong, X.; Wang, L. Drought Monitoring and Assessment Using Remote Sensing. In Remote Sensing of Hydrological Extremes; Lakshmi, V., Ed.; Springer: Cham, Switzerland, 2017. [CrossRef]

60. Arekhi, M.; Saglam, S.; Ozkan, U.Y. Drought monitoring and assessment using Landsat TM/OLI data in the agricultural lands of Bandar-e-Turkmen and Gomishan cities, Iran. Environ. Dev. Sustain. 2020, 22, 6691-6708. [CrossRef]

61. Kulkarni, S.S.; Wardlow, B.D.; Bayissa, Y.A.; Tadesse, T.; Svoboda, M.D.; Gedam, S.S. Developing a remote sensing-based combined drought indicator approach for agricultural drought monitoring over Marathwada, India. Remote Sens. 2020, 12, 2091. [CrossRef]

62. Tan, M.L.; Ibrahim, A.L.; Duan, Z.; Cracknell, A.P.; Chaplot, V. Evaluation of six high-resolution satellite and ground-based precipitation products over Malaysia. Remote Sens. 2015, 7, 1504-1528. [CrossRef]

63. Gopalkrishna, H.R.; Thiruvengadachari, S. Satellite derived regional vegetation dynamics over India as possible inputs to global climate models. In Proceedings of the IGARSS'93-IEEE International Geoscience and Remote Sensing Symposium, Tokyo, Japan, 18-21 August 1993; IEEE: Piscaway, NJ, USA, 1993; pp. 2059-2061.

64. West, H.; Quinn, N.; Horswell, M. Remote sensing for drought monitoring \& impact assessment: Progress, past challenges and future opportunities. Remote Sens. Environ. 2019, 232, 111291.

65. Huntington, J.L.; Hegewisch, K.C.; Daudert, B.; Morton, C.G.; Abatzoglou, J.T.; McEvoy, D.J.; Erickson, T. Climate engine: Cloud computing and visualization of climate and remote sensing data for advanced natural resource monitoring and process understanding. Bull. Am. Meteorol. Soc. 2017, 98, 2397-2410. [CrossRef]

66. Zhou, L.; Chen, N.; Chen, Z.; Xing, C. ROSCC: An efficient remote sensing observation-sharing method based on cloud computing for soil moisture mapping in precision agriculture. IEEE J. Sel. Top. Appl. Earth Obs. Remote Sens. 2016, 9, 5588-5598. [CrossRef]

67. Smith, W.K.; Dannenberg, M.P.; Yan, D.; Herrmann, S.; Barnes, M.L.; Barron-Gafford, G.A.; Biederman, J.A.; Ferrenberg, S.; Fox, A.M.; Hudson, A.; et al. Remote sensing of dryland ecosystem structure and function: Progress, challenges, and opportunities. Remote Sens. Environ. 2019, 233, 111401. [CrossRef]

68. Park, S.; Im, J.; Park, S.; Rhee, J. Drought monitoring using high resolution soil moisture through multi-sensor satellite data fusion over the Korean peninsula. Agric. For. Meteorol. 2017, 237, 257-269. [CrossRef]

69. Gonçalves, N.B.; Lopes, A.P.; Dalagnol, R.; Wu, J.; Pinho, D.M.; Nelson, B.W. Both near-surface and satellite remote sensing confirm drought legacy effect on tropical forest leaf phenology after 2015/2016 ENSO drought. Remote Sens. Environ. 2020, 237, 111489. [CrossRef] 
70. Jiao, W.; Wang, L.; McCabe, M.F. Multi-sensor remote sensing for drought characterization: Current status, opportunities and a roadmap for the future. Remote Sens. Environ. 2021, 256, 112313. [CrossRef]

71. Vicente-Serrano, S.M.; Quiring, S.M.; Pena-Gallardo, M.; Yuan, S.; Dominguez-Castro, F. A review of environmental droughts: Increased risk under global warming? Earth-Sci. Rev. 2020, 201, 102953. [CrossRef]

72. Alizadeh, M.R.; Nikoo, M.R. A fusion-based methodology for meteorological drought estimation using remote sensing data. Remote Sens. Environ. 2018, 211, 229-247. [CrossRef]

73. Van Leeuwen, W.J.; Orr, B.J.; Marsh, S.E.; Herrmann, S.M. Multi-sensor NDVI data continuity: Uncertainties and implications for vegetation monitoring applications. Remote Sens. Environ. 2006, 100, 67-81. [CrossRef]

74. McCabe, M.F.; Rodell, M.; Alsdorf, D.E.; Miralles, D.G.; Uijlenhoet, R.; Wagner, W.; Lucieer, A.; Houborg, R.; Verhoest, N.E.; Franz, T.E.; et al. The future of Earth observation in hydrology. Hydrol. Earth Syst. Sci. 2017, 21, 3879-3914. [CrossRef] [PubMed]

75. Rahmat-Samii, Y.; Manohar, V.; Kovitz, J.M. For Satellites, Think Small, Dream Big: A review of recent antenna developments for CubeSats. IEEE Antennas Propag. Mag. 2017, 59, 22-30. [CrossRef]

76. Zhu, X.; Chen, J.; Gao, F.; Chen, X.; Masek, J.G. An enhanced spatial and temporal adaptive reflectance fusion model for complex heterogeneous regions. Remote Sens. Environ. 2010, 114, 2610-2623. [CrossRef]

77. Hsbalkhalig, D.O.S. Efficiency Evaluation of MODIS Data Products in Monitoring and Mapping the Wild land Fire. Ph.D. Thesis, Sudan University of Science and Technology, Khartoum, Sudan, 2019.

78. Sterian, P.E.; Pop, F.; Iordache, D. Advance Multispectral Analysis for Segmentation of Satellite Image. In Proceedings of the International Conference on Computational Science and Its Applications, Melbourne, Australia, 2-5 July 2018; Springer: Cham, Switzerland, 2018; pp. 701-709.

79. Zhou, D.; Chen, J.; Bao, W.; Guo, Z. Water Resources Early Warning Study of MODIS cloud-precipitation relationship over the Wuxi River basin. In Proceedings of the 2018 ASABE Annual International Meeting, Detroit, MI, USA, 29 July-1 August 2018; American Society of Agricultural and Biological Engineers: St. Joseph, MI, USA, 2018; p. 1.

80. Rahimzadeh-Bajgiran, P.; Berg, A.A.; Champagne, C.; Omasa, K. Estimation of soil moisture using optical/thermal infrared remote sensing in the Canadian Prairies. ISPRS J. Photogramm. Remote Sens. 2013, 83, 94-103. [CrossRef]

81. Cheng, C.H.E.N.; Shuhe, Z.H.A.O. Drought monitoring and analysis of Huanghuai Hai plain based on TRMM precipitation data. Remote Sens. Land Resour. 2016, 28, 122-129.

82. Dinku, T. Challenges with availability and quality of climate data in Africa. In Extreme Hydrology and Climate Variability; Elsevier: London, UK, 2019; pp. 71-80.

83. Xu, C.; Wang, J.; Li, Q. A new method for temperature spatial interpolation based on sparse historical stations. J. Clim. 2018, 31, 1757-1770. [CrossRef]

84. Dhorde, A.G.; Patel, N.R. Spatio-temporal variation in terminal drought over western India using dryness index derived from long-term MODIS data. Ecol. Inform. 2016, 32, 28-38. [CrossRef]

85. Wang, R.; Bowling, L.C.; Cherkauer, K.A. Estimation of the effects of climate variability on crop yield in the Midwest USA. Agric. For. Meteorol. 2016, 216, 141-156. [CrossRef]

86. Sandholt, I.; Rasmussen, K.; Andersen, J. A simple interpretation of the surface temperature/vegetation index space for assessment of surface moisture status. Remote Sens. Environ. 2002, 79, 213-224. [CrossRef]

87. Wan, Z.; Wang, P.; Li, X. Using MODIS land surface temperature and normalized difference vegetation index products for monitoring drought in the southern Great Plains, USA. Int. J. Remote Sens. 2004, 25, 61-72. [CrossRef]

88. Jiao, W.; Zhang, L.; Chang, Q.; Fu, D.; Cen, Y.; Tong, Q. Evaluating an enhanced vegetation condition index (VCI) based on VIUPD for drought monitoring in the continental United States. Remote Sens. 2016, 8, 224. [CrossRef]

89. Kogan, F.N. Droughts of the late 1980s in the United States as derived from NOAA polar-orbiting satellite data. Bull. Am. Meteorol. Soc. 1995, 76, 655-668. [CrossRef]

90. Shen, Y.; Liu, X.; Huang, Y. Impacts of crop rotation on vegetation condition index for species-level drought monitoring. In Proceedings of the 2014 The Third International Conference on Agro-Geoinformatics, Beijing, China, 11-14 August 2014; pp. 1-5.

91. Quiring, S.M.; Papakryiakou, T.N. An evaluation of agricultural drought indices for the Canadian prairies. Agric. For. Meteorol. 2003, 118, 49-62. [CrossRef]

92. Kogan, F.N. Global drought watch from space. Bull. Am. Meteorol. Soc. 1997, 78, 621-636. [CrossRef]

93. Gitelson, A.A.; Kogan, F.; Zakarin, E.; Spivak, L.; Lebed, L. Using AVHRR data for quantitive estimation of vegetation conditions: Calibration and validation. Adv. Space Res. 1998, 22, 673-676. [CrossRef]

94. Bayarjargal, Y.; Karnieli, A.; Bayasgalan, M.; Khudulmur, S.; Gandush, C.; Tucker, C.J. A comparative study of NOAA-AVHRR derived drought indices using change vector analysis. Remote Sens. Environ. 2006, 105, 9-22. [CrossRef]

95. Singh, R.P.; Roy, S.; Kogan, F. Vegetation and temperature condition indices from NOAA AVHRR data for drought monitoring over India. Int. J. Remote Sens. 2003, 24, 4393-4402. [CrossRef]

96. Quiring, S.M.; Ganesh, S. Evaluating the utility of the Vegetation Condition Index (VCI) for monitoring meteorological drought in Texas. Agric. For. Meteorol. 2010, 150, 330-339. [CrossRef]

97. Melendez-Pastor, I.; Navarro-Pedreno, J.; Gómez, I.; Koch, M. Detecting drought induced environmental changes in a Mediterranean wetland by remote sensing. Appl. Geogr. 2010, 30, 254-262. [CrossRef]

98. Assan, E.; Suvedi, M.; Schmitt Olabisi, L.; Allen, A. Coping with and adapting to climate change: A gender perspective from smallholder farming in Ghana. Environments 2018, 5, 86. [CrossRef] 
99. OECD, Paris. TST Issues Brief: Water and Sanitation TST Issues Brief: Water and Sanitation. 2013. Available online: https:// sustainabledevelopment.un.org/content/documents/1801tstissueswater.pdf (accessed on 15 November 2021).

100. Mariano, D.A.; dos Santos, C.A.; Wardlow, B.D.; Anderson, M.C.; Schiltmeyer, A.V.; Tadesse, T.; Svoboda, M.D. Use of remote sensing indicators to assess effects of drought and human-induced land degradation on ecosystem health in Northeastern Brazil. Remote Sens. Environ. 2018, 213, 129-143. [CrossRef]

101. Bezner-Kerr, R.; McGuire, K.L.; Nigh, R.; Rocheleau, D.; Soluri, J.; Perfecto, I.; Hemming, D. Effects of industrial agriculture on climate change and the mitigation potential of small-scale agro-ecological farms. Anim. Sci. Rev. 2011, 69, 1-18.

102. Nkonya, E.; Gerber, N.; Baumgartner, P.; von Braun, J.; De Pinto, A.; Graw, V.; Kato, E.; Kloos, J.; Walter, T. The economics of desertification, land degradation, and drought toward an integrated global assessment. ZEF-Discuss. Pap. Dev. Policy 2011, 150, 1-198. [CrossRef]

103. Sepulcre-Canto, G.; Horion, S.M.A.F.; Singleton, A.; Carrao, H.; Vogt, J. Development of a Combined Drought Indicator to detect agricultural drought in Europe. Nat. Hazards Earth Syst. Sci. 2012, 12, 3519-3531. [CrossRef]

104. Freire-González, J.; Decker, C.; Hall, J.W. The economic impacts of droughts: A framework for analysis. Ecol. Econ. 2017, 132, 196-204. [CrossRef]

105. Assembly, U.G. High-Level Meeting on Addressing Desertification, Land Degradation and Drought in the Context of Sustainable Development and Poverty Eradication. A/65/861. 2012. Available online: https://digitallibrary.un.org/record/706202?ln=en (accessed on 15 November 2021).

106. Gisladottir, G.; Stocking, M. Land degradation control and its global environmental benefits. Land Degrad. Dev. 2005, 16, 99-112. [CrossRef]

107. Skogen, K.; Helland, H.; Kaltenborn, B. Concern about climate change, biodiversity loss, habitat degradation and landscape change: Embedded in different packages of environmental concern? J. Nat. Conserv. 2018, 44, 12-20. [CrossRef]

108. Kala, C.P. Environmental and socioeconomic impacts of drought in India: Lessons for drought management. Appl. Ecol. Environ. Sci. 2017, 5, 43-48.

109. Assessment, M.E. Ecosystems and Human Well-Being; Island Press: Washington, DC, USA, 2005; Volume 5, p. 563.

110. Li, P.; Omani, N.; Chaubey, I.; Wei, X. Evaluation of drought implications on ecosystem services: Freshwater provisioning and food provisioning in the Upper Mississippi River basin. Int. J. Environ. Res. Public Health 2017, 14, 496. [CrossRef] [PubMed]

111. Dennedy-Frank, P.J.; Muenich, R.L.; Chaubey, I.; Ziv, G. Comparing two tools for ecosystem service assessments regarding water resources decisions. J. Environ. Manag. 2016, 177, 331-340. [CrossRef] [PubMed]

112. Brauman, K.A. Hydrologic ecosystem services: Linking ecohydrologic processes to human well-being in water research and watershed management. Wiley Interdiscip. Rev. Water 2015, 2, 345-358. [CrossRef]

113. Lang, Y.; Song, W.; Zhang, Y. Responses of the water-yield ecosystem service to climate and land use change in Sancha River Basin, China. Phys. Chem. Earth Parts A/B/C 2017, 101, 102-111. [CrossRef]

114. Narasimhan, B.; Srinivasan, R. Development and evaluation of Soil Moisture Deficit Index (SMDI) and Evapotranspiration Deficit Index (ETDI) for agricultural drought monitoring. Agric. For. Meteorol. 2005, 133, 69-88. [CrossRef]

115. Kimm, H.; Guan, K.; Gentine, P.; Wu, J.; Bernacchi, C.J.; Sulman, B.N.; Griffis, T.J.; Lin, C. Redefining droughts for the US Corn Belt: The dominant role of atmospheric vapor pressure deficit over soil moisture in regulating stomatal behavior of Maize and Soybean. Agric. For. Meteorol. 2020, 287, 107930. [CrossRef]

116. Gupta, H.; Dube, L.C. Benefits of evaluating ecosystem services for implementation of nature-based solutions under the Paris agreement. In Social-Ecological Systems (SES); Springer: Cham, Switzerland, 2021; pp. 39-56.

117. Logsdon, R.A.; Chaubey, I. Ecosystem services: A need to move from concept to application. Resource 2012 , 3, 31.

118. Terrado, M.; Acuña, V.; Ennaanay, D.; Tallis, H.; Sabater, S. Impact of climate extremes on hydrological ecosystem services in a heavily humanized Mediterranean basin. Ecol. Indic. 2014, 37, 199-209. [CrossRef]

119. Bangash, R.F.; Passuello, A.; Sanchez-Canales, M.; Terrado, M.; López, A.; Elorza, F.J.; Ziv, G.; Acuña, V.; Schuhmacher, M. Ecosystem services in Mediterranean river basin: Climate change impact on water provisioning and erosion control. Sci. Total Environ. 2013, 458, 246-255. [CrossRef]

120. Mosley, L.M. Drought impacts on the water quality of freshwater systems; review and integration. Earth-Sci. Rev. 2015, 140, 203-214. [CrossRef]

121. Anderson, M.C.; Zolin, C.A.; Sentelhas, P.C.; Hain, C.R.; Semmens, K.; Yilmaz, M.T.; Gao, F.; Otkin, J.A.; Tetrault, R. The Evaporative Stress Index as an indicator of agricultural drought in Brazil: An assessment based on crop yield impacts. Remote Sens. Environ. 2016, 174, 82-99. [CrossRef]

122. Van Vliet, M.T.H.; Zwolsman, J.J.G. Impact of summer droughts on the water quality of the Meuse River. J. Hydrol. 2008, 353, 1-17. [CrossRef]

123. Dyosi, M.; Kalumba, A.M.; Magagula, H.B.; Zhou, L.; Orimoloye, I.R. Drought conditions appraisal using geoinformatics and multi-influencing factors. Environ. Monit. Assess. 2021, 193, 1-19. [CrossRef]

124. Seddon, A.W.; Macias-Fauria, M.; Long, P.R.; Benz, D.; Willis, K.J. Sensitivity of global terrestrial ecosystems to climate variability. Nature 2016, 531, 229-232. [CrossRef]

125. Sippel, S.; Reichstein, M.; Ma, X.; Mahecha, M.D.; Lange, H.; Flach, M.; Frank, D. Drought, heat, and the carbon cycle: A review. Curr. Clim. Chang. Rep. 2018, 4, 266-286. [CrossRef] 
126. Yuan, W.; Zheng, Y.; Piao, S.; Ciais, P.; Lombardozzi, D.; Wang, Y.; Ryu, Y.; Chen, G.; Dong, W.; Hu, Z.; et al. Increased atmospheric vapor pressure deficit reduces global vegetation growth. Sci. Adv. 2019, 5, eaax1396. [CrossRef] [PubMed]

127. FAO. Drought Impact Mitigation and Prevention in the Limpopo River Basin. 2004. Available online: http://www.fao.org/3/y5744e/ y5744e04.htm\#TopOfPage (accessed on 15 November 2021).

128. Klingebiel, S. Effectiveness and Reform of the United Nations Development Programme (UNDP); Psychology Press: London, UK, 1999; Volume 13.

129. Fang, J.; Lau, C.K.M.; Lu, Z.; Wu, W.; Zhu, L. Natural disasters, climate change, and their impact on inclusive wealth in G20 countries. Environ. Sci. Pollut. Res. 2019, 26, 1455-1463. [CrossRef]

130. Mujere, N.; Yadav, S.M. Adaption to Droughts. In Handbook of Drought and Water Scarcity; CRC Press: Boca Raton, FL, USA, 2017; pp. $75-94$.

131. Adaawen, S.; Rademacher-Schulz, C.; Schraven, B.; Segadlo, N. Drought, migration, and conflict in sub-Saharan Africa: What are the links and policy options? Curr. Dir. Water Scarcity Res. 2019, 2, 15-31.

132. Abel, G.J.; Brottrager, M.; Cuaresma, J.C.; Muttarak, R. Climate, conflict and forced migration. Glob. Environ. Chang. 2019, 54, 239-249. [CrossRef]

133. Kalaba, M. How Droughts Will Affect South Africa's Broader Economy. 2019. Available online: https://theconversation.com/ how-droughts-will-affect-south-africas-broader-economy-111378 (accessed on 15 November 2021).

134. Drummond, K. The Relationship between Droughts and the Tourism Industry: A Case Study on Cape Town, South Africa. 2019. Available online: https:/ /scholarworks.wmich.edu/honors_theses/3113/ (accessed on 15 November 2021).

135. Alberta WaterPortal. Social Impacts of Drought. 2014. Available online: https://albertawater.com/impacts-of-drought/socialimpacts-of-drought (accessed on 15 November 2021).

136. Mukamuhirwa, A.; Persson Hovmalm, H.; Bolinsson, H.; Ortiz, R.; Nyamangyoku, O.; Johansson, E. Concurrent drought and temperature stress in rice-A possible result of the predicted climate change: Effects on yield attributes, eating characteristics, and health promoting compounds. Int. J. Environ. Res. Public Health 2019, 16, 1043. [CrossRef] [PubMed]

137. Wutich, A.; Brewis, A.; Tsai, A. Water and mental health. Wiley Interdiscip. Rev. Water 2020, 7, e1461. [CrossRef]

138. Walz, Y.; Dall, K.; Graw, V.; de Villagran Leon, J.C.; Kussul, N.; Jordaan, A. Understanding and Reducing Drought Risk: Examples from South Africa and Ukraine; United Nations University-Institute for Environment and Human Security (UNU-EHS): Bonn, Germany, 2018.

139. Pal, B.D.; Kapoor, S.; Saroj, S.; Jat, M.L.; Kumar, Y.; Anantha, K.H. Impact of Laser Land Levelling on Food Production and Farmers' Income: Evidence from Drought Prone Semi-Arid Tropics in India; International Food Policy Research Institute: Washington, DC, USA, 2020; Volume 1960.

140. World Vision. Africa Hunger, Famine: Facts, FAQs, and How to Help. 2021. Available online: https://www.worldvision.org/ hunger-news-stories/africa-hunger-famine-facts (accessed on 15 November 2021).

141. Muyambo, F.; Jordaan, A.J.; Bahta, Y.T. Assessing social vulnerability to drought in South Africa: Policy implication for drought risk reduction. Jàmbá J. Disaster Risk Stud. 2017, 9, 1-7. [CrossRef]

142. Ferreira, S.M.; le Roex, N.; Greaver, C. Species-specific drought impacts on black and white rhinoceroses. PLoS ONE 2019, 14, e0209678. [CrossRef] [PubMed]

143. Pribyl, K.; Nash, D.J.; Klein, J.; Endfield, G.H. The role of drought in agrarian crisis and social change: The famine of the 1890s in south-eastern Africa. Reg. Environ. Chang. 2019, 19, 2683-2695. [CrossRef]

144. Desbureaux, S.; Damania, R. Rain, forests and farmers: Evidence of drought induced deforestation in Madagascar and its consequences for biodiversity conservation. Biol. Conserv. 2018, 221, 357-364. [CrossRef]

145. Shukla, S.; Arsenault, K.R.; Hazra, A.; Peters-Lidard, C.; Koster, R.D.; Davenport, F.; Magadzire, T.; Funk, C.; Kumar, S.; McNally, A.; et al. Improving early warning of drought-driven food insecurity in southern Africa using operational hydrological monitoring and forecasting products. Nat. Hazards Earth Syst. Sci. 2020, 20, 1187-1201. [CrossRef]

146. Tzanakakis, V.A.; Paranychianakis, N.V.; Angelakis, A.N. Water supply and water scarcity. Water 2020, 12, 2347. [CrossRef]

147. Fahad, S.; Bajwa, A.A.; Nazir, U.; Anjum, S.A.; Farooq, A.; Zohaib, A.; Sadia, S.; Nasim, W.; Adkins, S.; Saud, S.; et al. Crop production under drought and heat stress: Plant responses and management options. Front. Plant Sci. 2017, 8, 1147. [CrossRef]

148. Seleiman, M.F.; Al-Suhaibani, N.; Ali, N.; Akmal, M.; Alotaibi, M.; Refay, Y.; Dindaroglu, T.; Abdul-Wajid, H.H.; Battaglia, M.L. Drought stress impacts on plants and different approaches to alleviate its adverse effects. Plants 2021, 10, 259. [CrossRef]

149. Afuye, G.A.; Kalumba, A.M.; Orimoloye, I.R. Characterisation of Vegetation Response to Climate Change: A Review. Sustainability 2021, 13, 7265. [CrossRef]

150. Afuye, G.A.; Kalumba, A.M.; Busayo, E.T.; Orimoloye, I.R. A bibliometric review of vegetation response to climate change. Environ. Sci. Pollut. Res. 2021, 1-13. [CrossRef]

151. Littell, J.S. Drought and fire in the western USA: Is climate attribution enough? Curr. Clim. Chang. Rep. 2018, 4, 396-406. [CrossRef]

152. Taufik, M.; Veldhuizen, A.A.; Wösten, J.H.M.; van Lanen, H.A.J. Exploration of the importance of physical properties of Indonesian peatlands to assess critical groundwater table depths, associated drought and fire hazard. Geoderma 2019, 347, 160-169. [CrossRef]

153. Tokbergenova, A.; Nyussupova, G.; Arslan, M.; Kiyassova, S.K.L. Causes and impacts of land degradation and desertification: Case study from Kazakhstan. In Vegetation of Central Asia and Environs; Springer: Cham, Switzerland, 2018; pp. 291-302. 
154. Patz, J.; Corvalan, C.; Horwitz, P.; Campbell-Lendrum, D.; Watts, N.; Maiero, M.; Olson, S.; Hales, J.; Miller, C.; Campbell, K.; et al. Our Planet, Our Health, Our Future. Human Health and the Rio Conventions: Biological Diversity, Climate Change and Desertification. 2012. Available online: https://library.wmo.int/index.php?lvl=notice_display\&id=12101\#.YdhFMWhBzIU (accessed on 12 November 2021).

155. Fenta, L.; Kebede, A. Effect of Climate Change on Food and Water Borne Diseases Outbreak: A Mini Review. 2019. Available online: https://www.iiste.org/Journals/index.php/FSQM/article/view/48672 (accessed on 1 November 2021).

156. Logan, W.; Sheffield, J.; Wood, E. Applications of the African Flood and Drought Monitor to Vector-and Water-Borne Disease, and to Human Well-Being. 2019. Available online: https:/ /www.essoar.org/doi/abs/10.1002/essoar.10502411.1 (accessed on 5 October 2021).

157. Maystadt, J.F.; Ecker, O. Extreme weather and civil war: Does drought fuel conflict in Somalia through livestock price shocks? Am. J. Agric. Econ. 2014, 96, 1157-1182. [CrossRef]

158. Salmoral, G.; Ababio, B.; Holman, I.P. Drought impacts, coping responses and adaptation in the UK outdoor livestock sector: Insights to increase drought resilience. Land 2020, 9, 202. [CrossRef]

159. Schweighofer, J. The impact of extreme weather and climate change on inland waterway transport. Nat. Hazards 2014, 72, 23-40. [CrossRef]

160. Nouasse, H.; Rajaoarisoa, L.; Doniec, A.; Duviella, E.; Chuquet, K.; Chiron, P.; Archimède, B. Study of drought impact on inland navigation systems based on a flow network model. In Proceedings of the 2015 XXV International Conference on Information, Communication and Automation Technologies (ICAT), Sarajevo, Bosnia and Herzegovina, 29-31 October 2015; IEEE: Piscataway, NJ, USA, 2015; pp. 1-6.

161. Sheffield, J.; Wood, E.F.; Chaney, N.; Guan, K.; Sadri, S.; Yuan, X.; Olang, L.; Amani, A.; Ali, A.; Demuth, S.; et al. A drought monitoring and forecasting system for sub-Sahara African water resources and food security. Bull. Am. Meteorol. Soc. 2014, 95, 861-882. [CrossRef]

162. Cohen-Shields, N. How Climate Change Is Worsening Drought. 2021. Available online: https://blogs.edf.org/climate411/2021/ 04/30/how-climate-change-is-worsening-drought/ (accessed on 1 November 2021). 